\title{
МИЛИЦА МАЂАНОВИЋ
}

\section{АРХИТЕКТУРА ПРАТЕЋИХ ГРАЋЕВИНА ДВОРСКОГ КОМПЛЕКСА}

\begin{abstract}
Сажетак: Као решење које је обележило развој српске и југословенске архитектуре двадесетих и тридесетих година прошлог века, обликовано под утицајем комплексних политичко-идејних струјања међуратног периода, Дворски комплекс на Дедињу и данас представља једну од најрепрезентативнијих градитељских целина Београда и Србије. Овај рад, у којем ће бити изнета анализа архитектуре пратећих грађевина Краљевског двора, писан је са идејом да се начини први корак ка слојевитијем изучавању поменутог, до сада релативно занемариваног проблемског питања, које завређује веће интересовање стручне јавности јер, поред чињенице да у формалном и функционалном погледу чини нераскидиви део архитектонског ткива значајне културно-историјске целине лоциране на највишем брежуљку Дедиња, она својим облицима елаборира одјеке еклектичке интерпретације богатог српско-византијског, ренесансног и античког градитељског наслеђа доминантне, централне грађевине комплекса и представља сведочанство сегмента ауторског рукописа још увек недовољно расветљеног архитекте Живојина Николића.
\end{abstract}

Кључне речи: Дворски комплекс на Дедињу, Краљевски двор на Дедињу, архитектура, пратеће грађевине, међуратни период, архитекта Живојин Николић

Abstract: As a design which marked the Serbian and Yugoslav architecture of the 1920s and 1930s and which was shaped under the impact of complex political and ideological developments in the interwar period, the Royal complex in Dedinje remains one of the most prestigious architectural ensembles in Belgrade and Serbia. This paper, which offers an architectural analysis of the ancillary buildings of the complex, is meant to encourage a more comprehensive study of an unduly neglected issue: apart from the fact that the ancillary buildings are, formally and functionally, an integral part of the complex, an important cultural and historic site situated on the highest of Dedinje hillocks, they elaborate the eclectic interpretation of the rich Serbo-Byzantine, renaissance and classical stylistic legacy of the dominant building of the complex, and reveal a piece of the original handwriting of the still insufficiently illuminated figure of architect Živojin Nikolić. Nikolić

Keywords: Royal complex in Dedinje, Royal Palace in Dedinje, architecture, ancillary buildings, interwar period, architect Živojin

еђу остварењима која су обележила архитектонски развој српске и југословенске архитектуре првих деценија претходног столећа, Дворски комплекс на Дедињу се, несумњиво, може убројати у ред најзначајнијих. Грађевине од којих је сачињен, као и пажљиво компоновано решење парка који га употпуњава, оставиле су трага у градитељској делатности времена у којем су настале, а и данас представљају једну од најрепрезентативнијих архитектонских целина Београда и Србије. Архитектура стожерне тачке ширег дворског комплекса - Краљевског двора, из чијег се обликовања могу ишчитавати форме обједињених традиционалних елемената народне балканске варошке куће, ${ }^{1}$ европске аристократске виле у природи, ${ }^{2}$ монархове склоности ка руској империјалној уметности ${ }^{3}$ и општејугословенске културне тежње $\mathrm{e}^{-}$неизбежно је утицала на компоновање фасадних платана пратећих објеката подигнутих током прве фазе формирања резиденцијалне целине краљевске породице, са изузетком најстарије грађевине комплекса, Сламнате куће (сл. 1), пројектоване по угледу на сеоске куће Тополе, ${ }^{5}$ у карактеристичном рустично-сликовитом маниру.

Имајући у виду пријемчивост и допадљивост третмана фасадних платана, као и пажљиво конципирана решења планова, с јаким уверењем како би, да су подигнуте у склопу било ког другог архитектонског ткива, изван домета дугачких сенки импозантног присуства Краљевског и Белог двора, грађевине као што су пратећи објекти Дворског комплекса на Дедињу завределе више интересовања стручне јавности, овај рад писан је с циљем да се начини први корак ка њиховом слојевитијем изучавању. Овом приликом детаљно ће бити приказане карактеристике архитектонског обликовања пратећих грађевина Краљевског двора, као заокружене и кохерентне стилске целине. Након краћег осврта на грађу и релевантну литературу у којој се могу пронаћи 
Сл. 1 .

Сламнатиа кућа, üpegњa фacaga (Докуменйација ЗЗСКГБ, В-2389/8)

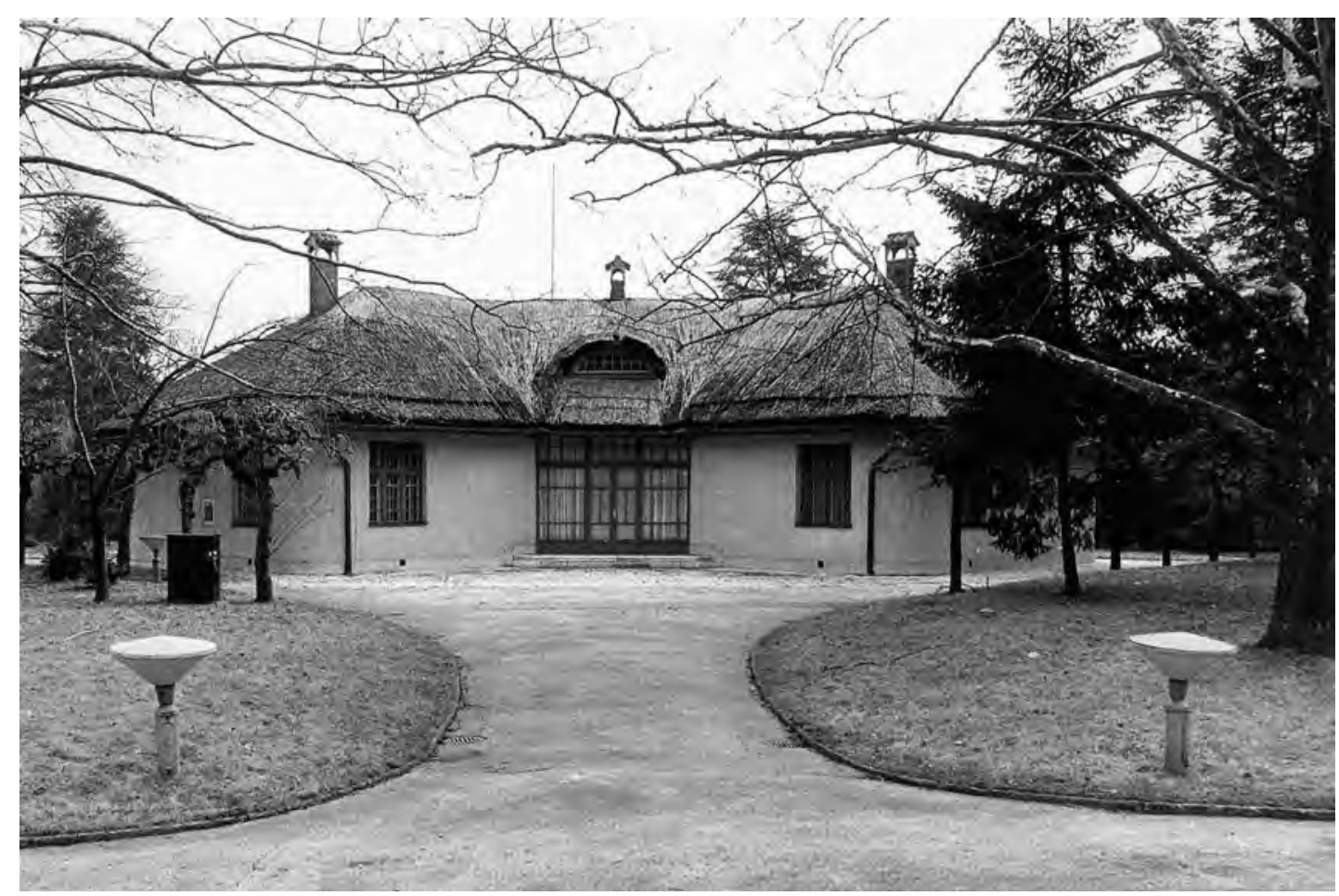

информације о архитектури Дворског комплекса на Дедињу, сажетог представљања историјата прве фазе његовог формирања и концизног изношења карактеристика обликовања спољашњости Краљевског двора, као жаришне тачке исијавања утицаја на формирање истовремено подизаних помоћних објеката, уследиће приказ решења основа и фасадних платана пратећих грађевина комплекса, подигнутих у периоду од 1924. до 1929. године.

Архивску грађу везану за архитектуру пратећих грађевина Дворског комплекса на Дедињу могуће је пронаћи у Архиву Југославије, фонд Двор Краљевине Југославије, бр. 74. Драгоцен извор података представља и опсежна документација Завода за заштиту споменика културе града Београда, прикупљена током процеса уврштавања Дворског комплекса на Дедињу у ред културних добара.

Иако је, још откако је постављен камен темељац старијег здања, Краљевског двора, комплекс често био у средишту пажње јавног мњења и праћен бројним сензационалистичким насловима, будући да је знатан део двадесетог века био затворен за ширу, а самим тим и стручну јавност, не чуди чињеница да се архитектонским питањима није подробније бавило дуго након његовог формирања. Пре књиге Милована В. Ивановића, чији наслов, чини се, с благом дозом ироније алудира на реалну ситуацију - Дворови на Деgињу: Срйски забрањени ірpag - објављене 1993. године, готово да и нема помена Дворског комплекса у стручној литератури. ${ }^{6}$ Пре овог првог исцрпног монографског огледа о дедињским дворовима, податке о Краљевском двору и придворној капели Светог Андрије Првозваног могуће је пронаћи у радовима Жељка Шкаламере о Николају Краснову, под називом Архийекӣа Никола Краснов (Москва 1864 - Београд 1939) из 1983. и Бојане Трпковић Сйари gвор на Деgињу из 1985. године. ${ }^{7}$ Након Ивановићеве монографије, повећао се број радова захваљујући којима је, мада посредно, будући да је њихов циљ по правилу било изучавање других проблемских питања, постало могуће доћи до значајније количине података у вези са архитектуром Дворског комплекса. Тако се у радовима Снежане Тошеве, Љиљане Милетић Абрамовић, Тијане Борић, Биљане Црвенковић, Александра Кадијевића, Александра Игњатовића, Милана Просена, Слободана Богуновића, у оквиру бављења наведених истраживача другим темама, може прочитати о архитектури, као и пројектантима Дворског комплекса на Дедињу. ${ }^{8}$ Допринос најскоријег датума у виду монографије насловљене Дворски комйлекс на Деgиюу, објављене 2012. године, која се бави изучавањем различитих аспеката комплекса, рад групе аутора, представља исцрпан преглед у оквиру којег је један сегмент посвећен архитектури комплекса - Краљевском и Белом двору, придворној капели Светог Андрије Првомученика и решењу дворског парка. ${ }^{9}$ Ниједан од поменутих радова не бави се, међутим, подробнијим изучавањем 


\section{АРХИТЕКТУРА ПРАТЕЋИХ ГРАЋЕВИНА ДВОРСКОГ КОМПЛЕКСА}

пратећих објеката подигнутих у било којој фази формирања Дворског комплекса - уколико су и поменути, то се чини узгредно, уз сведено представљање њихових најосновнијих карактеристика.

Идеја о подизању нове резиденције и измештању владарског дома из средишта града у удаљеније, мирније и интимније окружење потекла је од краља Александра Првог Карађорђевића лично, непосредно уочи венчања с румунском принцезом Маријом 21. јуна 1922. године. ${ }^{10}$ Изразито погодна позиционираност највишег брежуљка Дедиња, изолованог од градске вреве, али, истовремено, не претерано удаљеног, који представља изванредан видиковац на средиште и околину престонице, уједно омогућавајући визуелну доминацију и присутност нове резиденције владарске породице, условили су да се наметне као идеална локација нове краљевске резиденције. Највећи део терена који заузима Дворски комплекс, простирући се преко највишег брежуљка Дедиња површином од скоро 135 хектара земљишта, од чега већи део заузимају шума и парковски простор, припадао је Српској патријаршији, која је имање делом поклонила, делом продала, а делом уступила као компензацију за нека друга краљева имања по Србији. ${ }^{11}$ Сва имовина и објекти комплекса, изузев конструкције затвореног базена за купање са саунама, подигнуте накнадно, око 1966. године за савезне функционере, која обликовним карактеристикама и позицијом нарушава брижљиво компонован концепт првобитне целине, били су укњижени на Карађорђевићеве код надлежне власти града Београда - те су тадашњи власници за ову имовину плаћали и порез. ${ }^{12}$

Подизање Дворског комплекса на Дедињу може се сместити у хронолошки оквир између 1923. и 1937. године, при чему се издвајају две етапе формирања архитектонског ткива целине. Најстарији објекат комплекса уобличен је у виду питорескног интимно-рустичног решења Сламнате куће, подигнуте према пројекту Ива Валанда, чије је извођење до краја октобра 1923. године завршио Технички биро инжењера Л. Костића и М. Антића из Београда. ${ }^{13}$

Премда радови на уређењу ентеријера нове владарске резиденције нису окончани све до 1934. године, прва фаза архитектонског формирања целине може се пратити кроз период између 1924. и 1929. године, када је подигнут Краљевски двор с пратећим објектима (пријавна зграда, зграда дворске страже, економска зграда, кухиња, отворени базен са белим павиљоном и перголом, концертна дворана са перголом, придворна капела). ${ }^{14}$

Према сведочењима инжењера Смирнова, убрзо након усељења владарске породице у Краљевски двор на Дедињу, 1929. године, краљ Александар Први увидео је да ово интимно здање није довољно пространо да би примило читаву краљевску породицу. Идеја о градњи нове виле за краљевиће потекла је од самог краља, 1933. године, када је, према његовој жељи, израђен програм који је детаљно и прецизно одређен у погледу броја, величине, намене и распореда просторија. ${ }^{15}$ Нажалост, краљ Александар Први није доживео завршетак подизања овог здања - непуна два месеца након што је, 18. августа 1934. године, свечано положио камен темељац, убијен је у атентату у Марсељу. ${ }^{16}$ Имајући у виду, поред политичко-идејних струјања тренутка у којем је подигнут, и доминантан карактер спољашњег обликовања идејних решења конкурсних пројеката за Бели двор, не би било неосновано претпоставити како је чињеница да је регент, кнез Павле Карађорђевић, који је посао завршетка нове палате преузео на себе, утицала на његов данашњи изглед. Бели двор је, насупрот почетним идејним концепцијама, обликован у духу рафиниране интерпретације енглеске рецепције паладијанске архитектуре и својим елегантним линијама представља једно од најзначајнијих остварења српске архитектуре зрелог академизма. ${ }^{17}$ Другом фазом формирања Дворског комплекса на Дедињу, којом је уједно заокружена и продукована кохерентна, избалансирана архитектонска целина, може се, дакле, сматрати период између 1934. и 1937. године, када је, с пратећим објектима - кухињом и гаражом - грађен Бели двор.

Када је краљ Александар Први Карађорђевић донео коначну одлуку о потреби подизања нове резиденције, резултат је морао бити репрезентативно здање слојевитог комуникацијског карактера. Амбијенти Краљевског двора, иако је старији од два главна објекта и иницијално конципиран као приватан резиденцијални простор породице Карађорђевић - неизбежно су ангажовани како у функцији транспоновања доминантних идејних токова епохе у којем је подигнут тако и у илустровању моћи и достојанства краљевске династије. Као владарски дом, у којем се живот одвија према строго утврђеном протоколу, двор представља позорницу на којој ће иривайно неизоставно бити подређено јавном. ${ }^{18}$ Захваљујући широком репертоару форми и карактеристичном сложеном чулно-интелектуално-емоционалном непосредном контакту са човеком, архитектура, као један од основних градивних елемената човековог окружења и саставни део људског свакодневног искуства, посматрано кроз историју, представља изразито погодно средство преношења потенцијално слојевитог и широког дијапазона порука. Оквири владарских идеологија - које су унутар система патроната представљале један од кључних чиниоца реализације дела - диктирали су одређена естетска правила у складу са жељама и тежњама наручиоца. ${ }^{19}$ Претпоставке о изразито истакнутој улози нове резиденције породице Карађорђевић

\section{HACIE}




\section{МИЛИЦА МАЂАНОВИЋ}

у владарској идеологији и политици презентације суверена поткрепљене су, између осталог, како подацима о обимном ангажовању краља Александра Првог у свим сегментима прве етапе обликовања Дворског комплек$\mathrm{ca},{ }^{20}$ тако и чињеницом да је двор освећен 1929. године, на празник уједињења Краљевине СХC. ${ }^{21}$ Значај подухвата неизоставно је условио ангажовање низа утицајних архитеката и инжењера, еминентних уметника и престижних европских уметничких радионица, какви су били академик Николај Краснов, архитекти Живојин Николић, Виктор Лукомски, Александар Ђорђевић, Григорије Самојлов, инжењер Сергеј Смирнов и бечка радионица Бернхарда Лудвига. ${ }^{22}$

Све грађевине комплекса биле су, поред минуциозно изведене, репрезентативне уметничке обраде и опреме, опремљене најпрестижнијим савременим технолошким угодностима - унутар свих објеката уведен је телефон, централно грејање, ${ }^{23}$ комплекс је поседовао сопствену електричну централу... ${ }^{24}$ Аутентичну представу о животу краљевске породице у Дворском комплексу на Дедињу и механизмима функционисања целокупног имања пружају мемоари краља Петра Другог Карађорђевића:

Каgа ми је било шесй іоgина, иреселили смо се из нової gвора у Беоїраgу (који је саїраgио мој gеgа) у gвор на Деgиюу. Била је тио блистиава зіраgа на врху брgа, че-

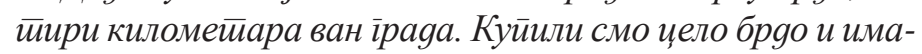

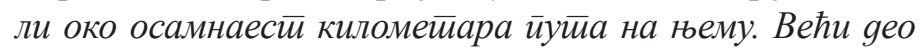
бряа био је йошумљен млаяом шумом, са нашом оїлеgном фармом у њеїовом йоgножју. Ову фарму је наязирао мој учитель јахања, ӣуковник у иензији. Имала је коњушнииу са сеgам или осам коња и обор са око gваgесети крава и свиња. Близу се налазила фарма йилића, ìge се јеgан Рус избеїлица, бивши іенерал, мислим, бринуо о свим моїу-

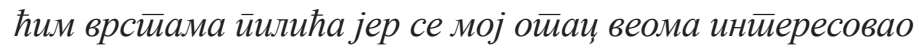
за живинарсииво. Уз саму кућу стиајала је омања ирква, иројекииована као кайела макеgонскоі манасииира. Моји мајка и ойаи су живели у великој кући док смо ми gеца и наше gаgиье имали сељачку кућу сазияану у облику иолукруїа, окружену йойолама и лејама са разнобојним иве-

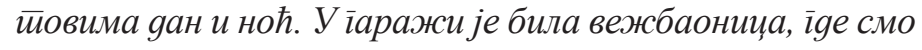
се забављали одбојком и іимнасиииком.

Цело имање је било обрађено и вођено йо најновијим мейоgама. Захваљујући елекииричној цеенирали исйоg іараже, били смо независни оg іраяске елекироgистирибуције, док су иумйа на елекииричну сиирују и иенитралне иећи снабgевале све куће на нашем земьиийу иарним ірејањем и йойлом воgом. Куће су биле йовезане лавиринииом ииунела кроз које су иролазиле цеви

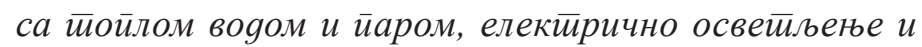
иелефонски каблови који су служили као среgствва за комуникаиију каgа је време било лоше. Најяужи ииунел, gуі йреко gва киломейра, ишао је оg gвора до іараже, gруїи йо яужини оg іараже до чувареве кућице. Храна

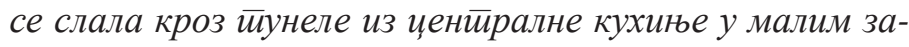
ірејаним камионетиима.

Имање је йакође имало зубну и лекарску орgинацију... Постиојале су йакође иекара, сииоларска и машинска раяионийа (йрава фабрика са сиируїовима и машинама за брушење) у великој зіраgи, ìge је била іаража. [...] Раgња са мешовитиом робом, снабдевена ирракииччно свачим, оg иілле и конца gо кукурузних йахуљиияа, сайуна, чоколаgе ийg., gо било кої резервної gела за ауйо или мойоцикл-и све йо йроизвояној изени! То је било чаробно месиио. ${ }^{25}$

Краљевски двор на Дедињу подигнут је према идејном решењу архитекте Живојина Николића, ${ }^{26}$ још увек неадекватно расветљене ауторске фигуре, школованог у Минхену, у класи чувеног професора Фридриха Тирша, који је уз помоћ Виктора Викторовича Лукомског - према општој процени историографа и савременика једног од најталентованијих руских архитеката у емиграцији ${ }^{27}$ - експедитивно, у периоду од фебруара до јула 1925. године, сачинио нацрте објеката Дворског комплекса на Дедињу.

Отменост и карактеристично сагласје лакоће и строгости уздржаног израза карактеришу спољашно и унутрашње архитектонско обликовање Краљевског двора. Репрезентативност и отменост ансамбла ефективно су акцентоване академски прецизно изведеним детаљима пластике и унутрашње декорације - стубовима, зидним орнаментима, порталима, нишама, аркадама, терасама у приземљу, сутерену и на спрату. Двојаки карактер палате - јавне позорнице значајних историјских догађаја и, уједно, приватног дома владарске породице - наглашен је одвајањем свечаног и официјелног од резиденцијалног дела грађевине. Приземље, конципирано као простор намењен јавном, официјелним пријемима и дочеку посетилаца, одликује се академски обликованим, прегледним планом у чије је средиште постављен свечани хол, основна комуникациона тачка нивоа. Северно од дворске зграде налази се унутрашње двориште са скулптурама у центру и аркадним тремом, који повезује Цркву Светог Андреја Првозваног са краљевом резиденцијом, а у чијем се решењу, без сумње, огледа Красновљев утицај. ${ }^{28}$

Иако се чврстим академским линијама монолитна кубична форма палате намеће као строга, уздржана композиција, она не оставља утисак тежине већ одише својеврсним спокојством и лакоћом израза. Чврстина зидних платана оживљена је отворима, разиграном пластиком и ритмовима контрастних истурених и увучених сегмената - ризалита, еркера, тремова и тераса. Разноврсно, суптилно компоноване фасаде различитих визура, окренуте аркадијанским парковским просторима 


\section{АРХИТЕКТУРА ПРАТЕЋИХ ГРАЪЕВИНА ДВОРСКОГ КОМПЛЕКСА}

украшеним скулптурама и разнобојном вегетацијом, упркос сведености облика на основне елементе (лук, трем и кров), одликују се динамичношћу и допадљивим дијалогом с природним амбијентом, чије зеленило истиче блиставу белину оплате зидних платана, и доприносе коначном утиску хармоничне целине која плени својом једноставношћу и љупкошћу облика.

Питање интерпретације стила у којем је подигнут Краљевски двор на Дедињу може се издвојити као отворено. Индикативно је да се у официјелним документима Министарства иностраних послова Краљевине Југославије, систематизованим у Архиву Југославиje, уместо југословенског стилског концепта наводи да је програм нове краљеве резиденције био боїайо заснован у стиллу срйске визанииинике, а помиње се и умерени визанииијски склой са ирименом домаћих мойива. Уз то, ни позната опредељења монарха, кога су упућени савременици окарактерисали као йоборника оживљавања и настиављања сиррско-визанииијскоі стиила, не иду у прилог претпоставци о југословенском стилском карактеру резиденцијалног здања, већ пре подупиру залагања српских архитеката за континуитет националног стила, утемељеног у ранијим епохама. ${ }^{29}$

Међутим, посматрано кроз призму познате тежње краља Александра с краја двадесетих година прошлог века, ка хомогенизацији националних културних разлика народа над којима је владао под окриљем идеологије југословенства, чини се подстицајним виђење Александра Игњатовића, који као најупечатљивије у архитектонском лику дедињског двора наводи изразит стилски еклектицизам. Он истиче да необичну синтезу облика и мотива чине различити архитектонски елементи који потичу из неколико градитељских традиција. Ту су, најпре, мотиви вернакуларног градитељства варошке балканске куће (организација простора око централног језгра, доксати, тремови, еркери, димњачке главе ћерамида као кровни покривач); затим елементи блиски облицима познатим из византијске архитектуре (капители са импостима, бифоре, трифоре, аркаде); насупрот њима, артикулација читавог склопа као и систем рашчлањивања били су у традицији западног градитељства и уобичајених решења архитектуре академизма. Поред наведеног, за пореклом обиља архитектонских детаља на фасадама (касетиране стрехе, класична профилациja, иконографија камене пластике) и у ентеријеру (класицизирајући елементи попут коринтских и композитних стубова, касетираних таваница) може се трагати у богатом формалном репертоару античке и ренесансне apхитектуре. ${ }^{30}$ Уколико се интерпретацији форми присутних у обликовању Краљевског двора приступи на овај начин, како Игњатовић закључује, читиав geguњ-

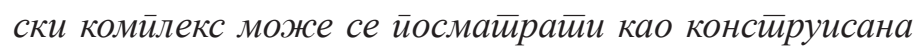

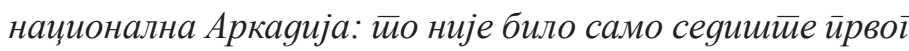
и најзначајнијеі йройаїонистие јуїословенстива, краља Алексаняра Првої Карађорђевића, већ gо крајности

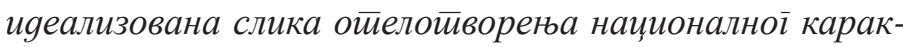

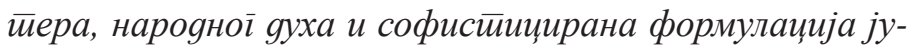
іословенской ияенииитейа, орїанизована йуиемм неколико кулииуролошких механизама. ${ }^{31}$

Као што је у литератури примећено, можда је најприкладнију претпоставку могуће донети на основу повезивања наведених становишта - чини се да формални израз Краљевског двора на Дедињу плодно обједињује тежње за национално препознатљивим обликовањем архитектонског вокабулара, захваљујући коме нова краљева резиденција заузима високо место у фолклористичкој грани новог српског стила, с монарховим захтевима за интегралном југословенском културом, потврђујући потенцијал нове цивилизацијско-уметничке синтезе, при чему је, у идеолошком погледу, помогнуто устоличење југословенске друштвене парадигме. ${ }^{32}$

Посматрано кроз призму функционалности, захваљујући својој позиционираности на пространом имању изван згуснутог урбанистичког ткива градског околиша, зграда Краљевског двора је формално могла бити обликована у складу с примарним, иницијалним концепцијама резиденцијалног и репрезентативног карактера. Одабрана локација омогућила је растерећивање простора главне грађевине комплекса - нове резиденције владарске породице - механизама свакодневног животног функционисања дворског имања, те њихово смештање у засебне, у складу са специфичним потребама пројектоване, пратеће објекте. Имајући претходно поменуто на уму, не чуди чињеница да је, паралелно с подизањем нове владарске резиденције, на територији комплекса изграђен низ помоћних објеката. У првој фази формирања Дворског комплекса на Дедињу, главни архитекта Живојин Николић, вођен прецизно формулисаним визуелним идентитетом централне грађевине целине, обликовао је пратеће објекте под утицајем истоветне, особене интерпретације традиције и формалне артикулације доминантних идејних струјања историјског момента, које су у третману помоћних грађевина изражене на сведен, али изразито допадљив и декоративан начин. ${ }^{33}$

Приближно четрдесет метара од главне дворске капије, надомак тачке у којој се раздвајају путеви који воде према Краљевском и Белом двору, смештена је грађевина невеликих димензија - укупне површине 388,5 м²,34 дворска жандармерија, позната и као портирска зграда (сл. 2). До Другог светског рата, за време Краљевине Југославије, коришћена је као дворска жандармеријска станица, а касније је у њој био смештен почасни вод Титове гарде. ${ }^{35}$ 
Сл. 2.

Зіраяа дворске жаняармерије, заgна фасаgа (Докуменйација 3ЗСКГБ, B-2406/15)

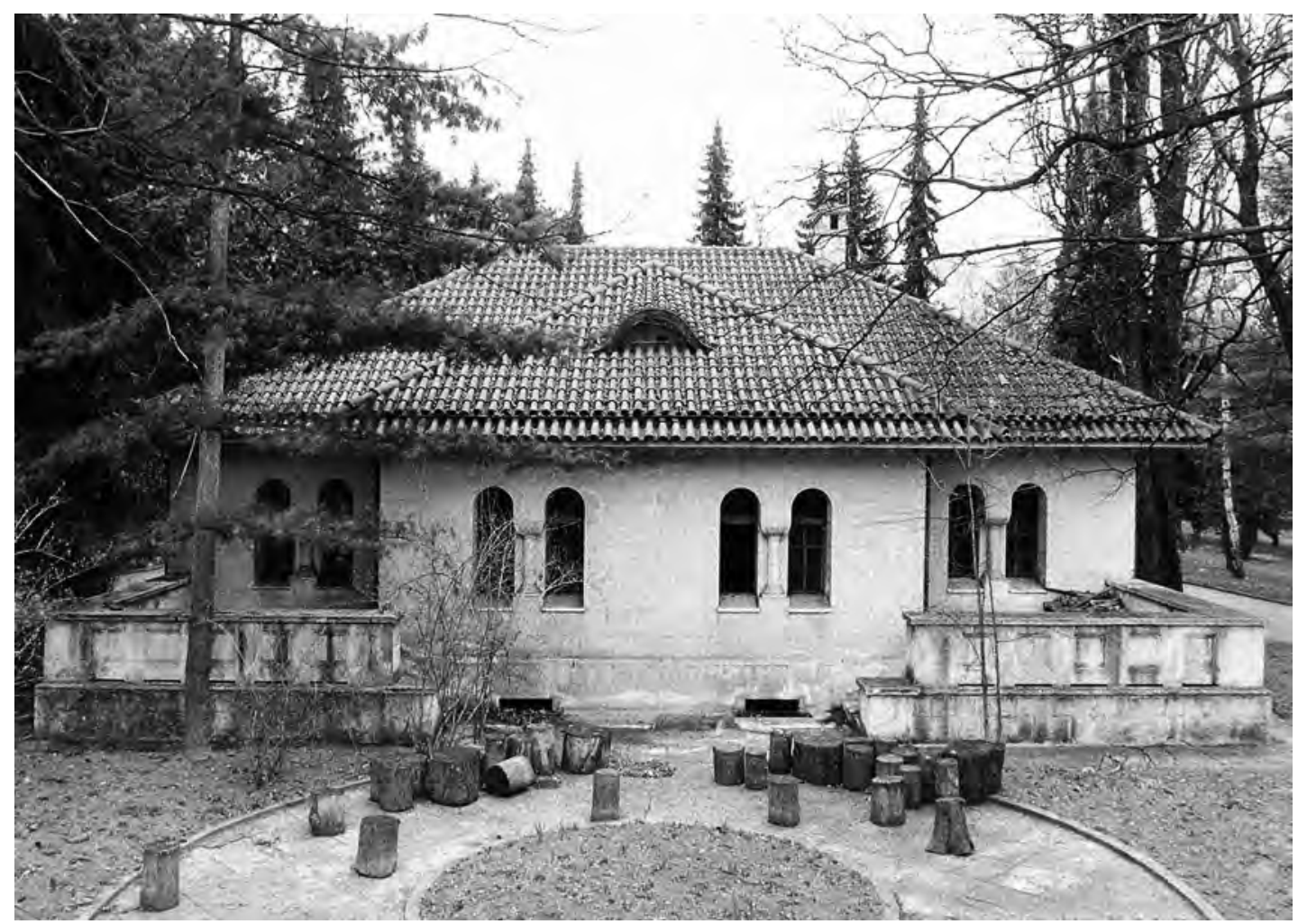

Прегледна, симетрична композиција, систематичне, академски прецизне артикулације простора карактерише решење основе ове визуелно ненаметљиве грађевине. Трима степеницима, испод лука који почива на масивним, премда ниским ступцима ограде, долази се до правоугаоне лођије невеликих димензија, из које је могуће приступити у три просторије. На краћој, левој страни налазе се врата која воде до собе за іовор, наспрам које се, попут одраза у огледалу, кроз врата отворена на десној страни трема, може ући у канцеларију са засебним тоалетом. Кроз централна, лучно завршена врата смештена на дужој страни трема, улази се у предсобље, главну комуникациону тачку приземља. Из предсобља се, кроз отворе смештене на краћим страницама просторије, лево може приступити просторији с купатилом, а десно кухињи, која је повезана и с претходно поменутом канцеларијом. На подужном зиду предсобља, наспрам улазних врата, кроз двоја врата могуће је ући у две, међусобно повезане просторије, које су са спољашње стране, у односу на раван зидног плата, истурене у простор и покривене засебним, троводним кровним покривачем. Распоред просторија подрума у потпуности следи решење приземља.

Прецизна, читка подела простора присутна је и у спољашњем третману кубичне грађевине доминантне хоризонтале, чија су зидна платна подељена у два фасадна појаса складних пропорција. Примена четвороводног крова, који у формалном погледу комуницира како са доминантним решењем Краљевског двора, тако и, просторно ближим, здањем дворске страже, доприноси динамици и живописности контуре горње зоне фасада. Превазилажење монотоније остварено је извођењем суптилне вертикале, пресецањем кровног покривача са сваке стране грађевине отвореним лучно завршеним прозорима малих димензија - мотив особен за објекте дедињског комплекca, са изузетком кухиње заступљен на свакој грађевини целине, као и апликацијом два карактеристична висока димњака, који евоцирају облике заступљене у ризници типолошких и формалних елемената архитектонског вокабулара народног неимарства. ${ }^{36}$ Доња зона главне фасаде грађевине, оживљена апликацијом карактеристичне троструке улазне аркаде, фланкиране витким бифорама бочних ризалита, одликује се својеврсном љупкошћу и лакоћом израза, док се нижи појасеви бочних и задње фасаде одликују динамичном контуром ритма увучених и истурених зидних маса.

Уколико се третман предње и задње фасаде упореди са обликовањем одговарајућих површина (источна и западна фасада) Краљевског двора могуће је уочити својеврсну игру супституције форми, која, била резултат ауторове намере или, пак, случајан ефекат преовлађујућих тенденција архитектонског израза, суптилно усмерава 


\section{АРХИТЕКТУРА ПРАТЕЋИХ ГРАЪЕВИНА ДВОРСКОГ КОМПЛЕКСА}

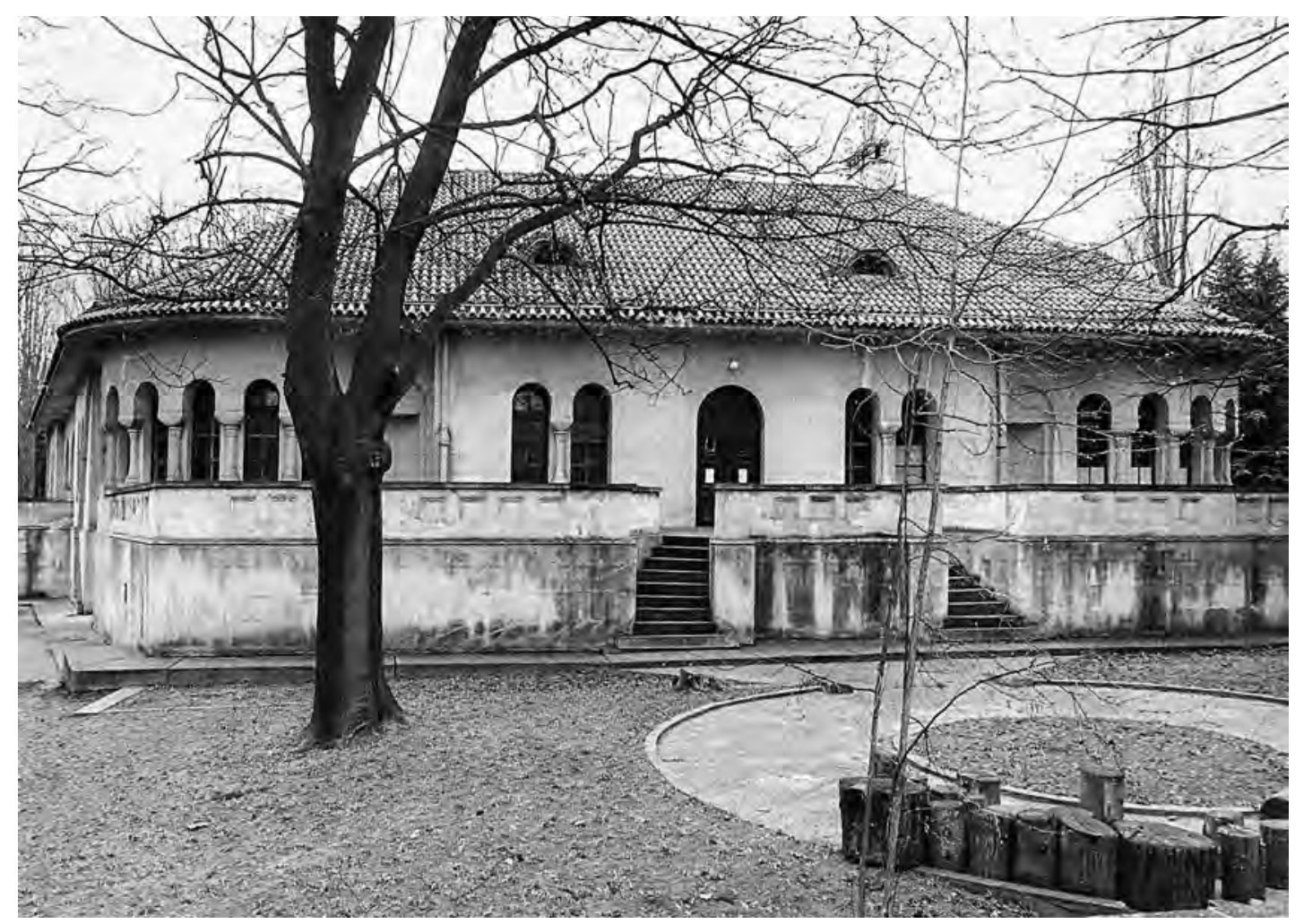

Сл. 3.

Зі̄paga вворске

стираже,

заяња фасаgа

(Докуменйаиија

ЗЗСКГБ, B-2406/17)

посматрача ка решењу обликовања владарске резиденције, формалном и идејном средишту целине. Мотив троструке аркаде, фланкиране бифорама смештеним на бочним партијама доње зоне зидног платна предње фасаде прве грађевине на коју посетилац овог дворског комплекса наилази, у прикладно комплекснијем, раскошнијем облику присутан је на западној фасади централне грађевине комплекса, Краљевском двору, док је форма истуреног централног ризалита источне фасаде владарске резиденције поновљена, разуме се - у сведенијој варијанти, у третману задње стране портирске зграде. Хармонична комуникација са грађевином намењеном дворској стражи, смештеној непосредно иза ње, остварује се двоструко - оплатом од клесаних плоча блиставобелог брачког камена ${ }^{37}$ и апликацијом лучно завршених бифора, раздвојених колонетом карактеристичног облика. Иако невеликих димензија и ненаметљиве форме, захваљујући читком, академски прецизном третману, како спољашњег тако и унутрашњег простора, као и примени питорескних, премда примерено сведених декоративно обликованих мотива присутних и на осталим, према функцији значајнијим, здањима комплекса, зграда дворске жандармерије допадљивом контуром и бритко конципираном спољашњом обрадом представља веома успешно решење које носи несумњив печат свог творца, архитекте Живојина Николића.
Непосредно иза дворске жандармерије смештена је формално упечатљивија грађевина дворске страже, која заједно са скромнијим објектом формира хармоничну функционалну и визуелну целину (сл. 3). У овом објекту била је смештена почасна јединица Краљеве гарде, која је обављала стражарску дужност и одавала почаст у складу са дворским протоколом. ${ }^{38}$

Динамично компоновање унутрашњих простора полигоналне основе објекта уравнотежено је прегледним, симетричним концептом академски формираног ауторског рукописа архитекте Живојина Николића, који потписује пројекте свих помоћних грађевина комплекса. Основну комуникациону тачку приземља представља централни ходник, из којег се може приступити како вишем и нижем нивоу (поткровљу и сутерену), тако и левом и десном крилу грађевине, артикулисаним попут одраза у огледалу. С леве стране се, једне на друге, надовезују просторије намењене официрима и унуйрашњој сииражи, а са десне су смештене собе за наредну смену и сйољашњу сииражу. Карактеристична хармонична динамичност плана постигнута је допадљивим наизменичним компоновањем кружних и различито оријентисаних правоугаоних форми просторија: углови средишњег тракта основе акцентовани су кружним постројењима која фланкирају две, лево и десно од улазног ходника смештене, правоугаоне 


\section{МИЛИЦА МАЂАНОВИЋ}

просторије мањих димензија - собу намењену официрима и собу намењену наредној смени, док су подужно оријентисане средишње просторије бочних крила оивичене мањим, у односу на лонгитудиналну осу њиховог простирања, попречно постављеним одајама. План сутерена у потпуности понавља артикулацију приземља - у кружним, на угловима постављеним постројењима били су смештени магацини, а централне, подужно оријентисане просторије бочних крила коришћене су као трпезарије за стражу.

Наглашена непрекинутом површином четвороводног кровног покривача, применом низа лучно завршених отвора и високим, благо истуреним соклом, олакшаним равно завршеним прозорима сутерена, доминантна хоризонтала, присутна у моделовању архитектонског волумена и фасадних површина, оживљена је ритмом динамично компонованих облика, који следе полигоналну основу грађевине. Чврста симетрија академски рашчлањене композиције главне фасаде здања ублажена је разиграним ритмом отвора и волумена доњег појаса - зидно платно централног ризалита, олакшано лучно завршеним вратима смештеним између две витке бифоре, фланкирано је истуреним, кружним постројењима оживљеним љупким низом лучних прозора, одељених карактеристичним колонетама. Мотив од тла одигнуте троструке улазне аркаде којој се приступа степеницима, заступљен на готово свим грађевинама комплекса, у згради дворске страже присутан је на централним ризалитима бочних фасада и акцентован бочним ризалитима, олакшаним лучно завршеним трифорама. Хармоничне размере, динамично осмишљено просторно решење, прецизно артикулисани волумени, конструктивна чврстина, као и допадљиво интерпретирани, сведени декоративни мотиви диктирају допадљивост и ненаметљиву, али осетну снагу израза зграде дворске страже.

На простору недалеко од некадашњег споредног, техничког улаза, у истој оси с павиљоном белведере и Краљевским двором, физички и функционално издвојен, подигнут је утврђењу налик објекат који се може тумачити као прагматични центар дедињског комплекса - здање дворске економије, грађевина у којој је био смештен комплексан, разгранати систем Управе двора, као и различите попратне службе чија су задужења била везана за омогућавање неометаног функционисања свакодневног дворскога живота (сл. 4). У функционалном погледу најзначајнија међу пратећим грађевинама комплекса, зграда дворске економије одликује се пропорционално комплексним решењем плана, репрезентативнијим карактеристикама обликовања и пространијим димензијама.

Из концепције рационално артикулисаних простора комплексне, разуђене основе обликоване према ћириличном слову П, ишчитава се систематичност, прецизан, академски формиран ауторски рукопис и таленат архитекте Живојина Николића да прегледно, у хармоничну целину повеже велики број функционално разноликих јединица. Око средишњег дворишта, на три нивоа, распоређене су правоугаоне просторије различитих димензија, у којима су били смештени носиоци

\section{Сл. 4.}

Економска зіраяа, ойшӣи изӣлеg (Докуменйащија 3ЗСКГБ, B-2406/27)

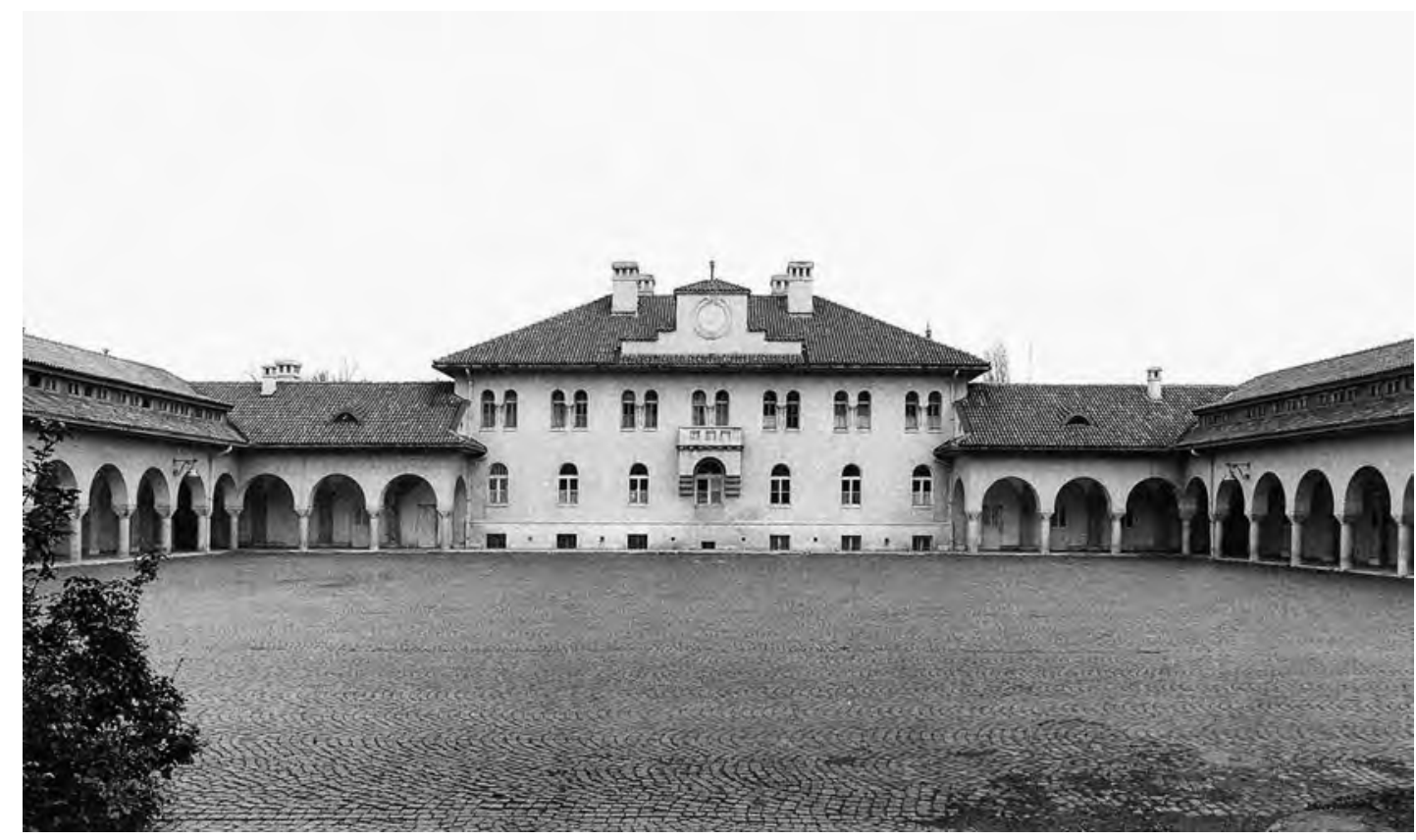




\section{АРХИТЕКТУРА ПРАТЕЋИХ ГРАЪЕВИНА ДВОРСКОГ КОМПЛЕКСА}

и извршиоци механизама заслужних за неометано одвијање дворске свакодневице. У централном тракту сутерена налазиле су се трпезарије и кухиња намењене запосленима на имању, док су у бочним постројењима, између осталих, били смештени подруми, остава за зимницу и просторија са централним системом парног грејања. Простори у приземљу служили су најразноликијим наменама - од штале, преко канцеларија, разноврсних радионица (браварска, столарска, седларска итд.) и одаје за дежурног шофера, до перионица и гараже. Иако су засебна степеништа водила до спратова сваког тракта грађевине, у сваком сегменту објекта примењен је идентичан систем артикулације простора - из централног ходника, који се простире целом дужином нивоа, приступа се низу правоугаоних просторија смештених са обе његове стране.

Чврсто, академски прецизно рашчлањивање површина и волумена наглашене симетрије присутно је и у обликовању спољашње архитектуре грађевине. За остале пратеће грађевине карактеристична, доминантна хоризонтала, у случају зграде дворске економије суочена је с вертикалним акцентовањем елевације кровног покривача бочних трактова, који чине визуелни прелаз између простирања ниских дугачких силуета ка, за спрат вишем, централном ризалиту објекта. Акцентовање средишње вертикале централног ризалита економске зграде, изведено је помоћу кубичне, балдахину налик конструкције каменог балкона, употребљеног да би се вертикална форма лучних врата довела у визуелну конекцију с централном бифором горњег низа прозорских оквира, у односу на чију средишњу осу је конструисана степенаста, пирамидално завршена сатна кула, наглашена апликацијом четири карактеристична димњака. Приказано акцентовање средишњег тракта здања дворске економије можда би било могуће интерпретирати у светлу далеких одјека комуникације са источном фасадом Краљевског двора, чија је средишња вертикала наглашена низом архитектонских мотива. Чврстом ефекту тока хоризонталних линија централног тракта грађевине, који је потцртан апликацијом седам лучно завршених бифора у горњем, седам лучних отвора у средњем и шест равно завршених прозора најнижег појаса главног фасадног платна, а настављен строгом контуром кровног покривача истурених бочних трактова, олакшаном низом ниских, правоугаоних прозора - подарена је својеврсна лакоћа израза мотивом отвореног, љупког аркадног приземља. Грађевина дворске економије плени једноставношћу форми и сведеном љупкошћу прегледно рашчлањених волумена, док се умешност њеног аутора, поред успешног компоновања допадљиве ненаметљиве хармоније облика, огледа и у рационалности унутрашњег распореда.

Намена последње помоћне грађевине подигнуте у првој фази формирања Дворског комплекса на Дедињу која ће овом приликом бити обрађена условила је њено лоцирање недалеко од Краљевског двора (сл. 5). Премда се у литератури наводи да разлог за изостављање кухиње из простора владарске резиденције потиче од настојања краља Александра да онемогући продирање кухињских мириса, ${ }^{39}$ логичнијом се чини претпоставка

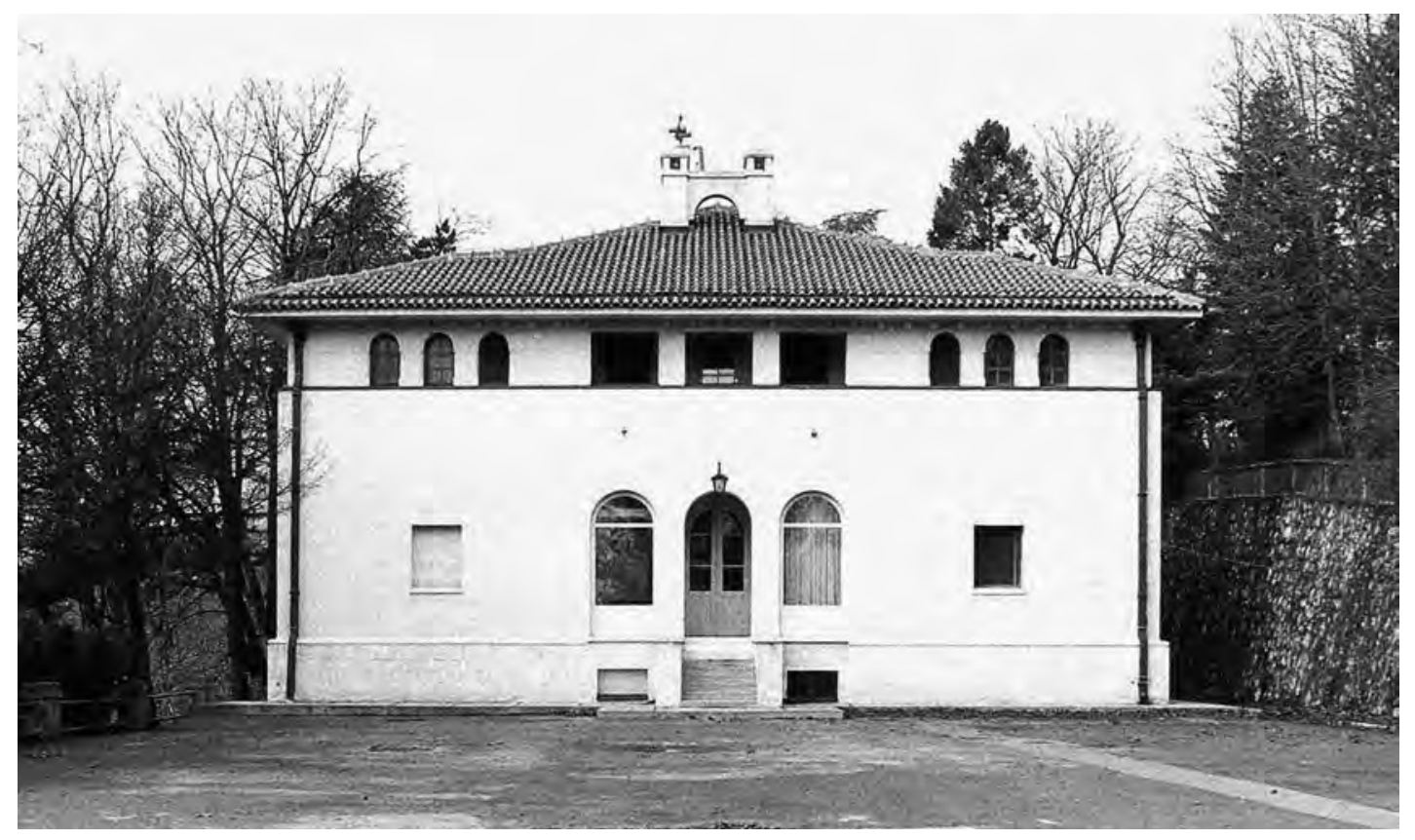

Сл. 5.

Зіраяа дворске кухиње, uрpegra фасаga (Докуменйаиија 3ЗСКГБ, В-2389/10) 


\section{МИЛИЦА МАЂАНОВИЋ}

да се узрок може потражити како у незанемарљивим димензијама самог објекта $\left(1006,50 \mathrm{~m}^{2}\right),{ }^{40}$ незахвалним за укључивање у концепт решења основе палате, чији би унутрашњи распоред несумњиво пореметиле, тако и у пространству имања довољном да подржи формулацију проблематичног простора у виду засебног објекта. Кухиња је с трпезаријом и помоћним просторијама Краљевског двора повезана подземним тунелом, дугим готово деведесет метара.

Приметно најједноставније конципиране спољашње обраде ${ }^{41}$ зграда кухиње се одликује изузетно прегледним, симетрично конципираним решењем распореда унутрашњих простора, које је, уз минимална одступања, примењено на сва три нивоа објекта. И у случају артикулације кухињског простора, архитект је као централну комуникациону тачку поставио лонгитудинално оријентисани ходник из којег је могуће приступити готово свим просторијама спрата, док је истурањем четири угаоне просторије у простор визуелно и формално акцентовао углове грађевине. У сутерену и приземљу су смештени простори који су били намењени припреми и конзервирању хране, док су се на спрату налазиле просторије за смештај кухињског особља.

Главна фасада грађевине третирана је сведено, са суптилно наглашеном игром ритмова хоризонтала, вертикала и волумена, оствареном контурама кровног покривача и отвора, као и обликовањем благо истурених угаоних ризалита и њиховим наглашавањем у кровном покривачу. Стиче се, међутим, утисак неадекватно остварене комуникације зона фасаде, при чему четвороводни кровни покривач, обликован у маниру карактеристичном за све објекте дворског комплекса изграђене у периоду од 1923. до 1929. године, превише тешко притиска уску зону спрата, не успевајући визуелно да парира превише широком доњем појасу, оживљеном отворима који додатно наглашавају безразложно велику површину празног зидног платна. Обликовање бочних фасада, са успешније компонованим односом хоризонталних појасева и димензија отвора и зидних платана, оставља складнији утисак. И овде, особену хоризонталну кубичност грађевине оживљавају благо наглашене вертикале бочних ризалита, акцентоване апликацијом витких, лучно завршених бифора одвојених карактеристичном колонетом, на које се, у горњој зони надовезују по три лучне монофоре. Динамика, као и хармоничније повезивање вертикалних и хоризонталних линија, централне партије бочне фасаде постигнути су отварањем трију лучних масивних прозора у доњој зони, изнад којих су, на оси средишње линије њихових размака, отворена два невелика кружна отвора, а у горњем фасадном појасу, центриране према осама нижих, већих прозорских отвора, постављене су мање, лучно завршене монофоре. Вероватно сразмерно карактеру објекта најмање репрезентативне намене, као и релативном заклоњеношћу од погледа виђенијих посетилаца, спољашња обрада кухињске зграде је најскромнија - чињеница која не помрачује прецизно, рационално решење основе објекта, као ни печат карактеристичног рукописа архитекте Живојина Николића.

Одговарајући на комплексна и турбулентна политичко-идејна струјања епохе, решење Краљевског двора - изведено у виду пажљиво састављеног семиотичког комуникацијског система, чији је резултат репрезентативна синтеза архитектонског вокабулара која је својим облицима инспирисала низ идејних решења савремених архитеката ${ }^{42}$ - утицало је својим формама и на обликовање пратећих грађевина Дворског комплекса на Дедињу. Иако, логично, архитектура попратних објеката није третирана репрезентативно као Краљевски двор, завређује интересовање јер, поред чињенице да у појавном и функционалном погледу чини нераскидиви део значајне културно-историјске целине, Дворског комплекса на Дедињу, она својим облицима обрађује одјек питорескне еклектичке интерпретације богатог српско-византијског, ренесансног и античког градитељског наслеђа доминантне, централне грађевине и представља сведочанство сегмента ауторског рукописа до сада недовољно расветљеног градитеља, какав је Живојин Николић. Будући да је конципиран с идејом иницијалног скретања пажње стручне јавности ка проблематици архитектуре пропратних грађевина Дворског комплекса на Дедињу, а не с циљем да исцрпи све сложене аспекте изучавања поменуте тематике, овај рад, надамо се, представља први корак ка дубљој критичкој проблематизацији чињеница овом приликом изнетих, будућим плодним компарацијама са сличним целинама у земљи и иностранству, као и подробнијим изучавањима Сламнате куће и пратећих објеката Белог двора.

Милица Б. Мађановић, историчар уметности

Београд mmadjanovic@gmail.com 


\section{АРХИТЕКТУРА ПРАТЕЋИХ ГРАЪЕВИНА ДВОРСКОГ КОМПЛЕКСА}

\section{НАПОМЕНЕ:}

1] Дероко 1964; 1968.

2] Ackerman 1990

3] Јовановић 1994: 93-97; Кадијевић 1994: 243-254; 2002-2004: 131-142.

4] Ignjatović 2007 .

5] Документација ЗЗСКГБ о Дворском комплексу на Дедињу.

6] Ивановић 1993.

7] Шкаламера 1983: 109-129; Трпковић 1985: 100-105.

8] Ивановић 1993; Тошева 1994: 302-307; Кадијевић 1994а: 243-254; 1994в: 181-192; 1997а: 147-149; 1997б: 221-255; 1998-1999: 115-132; 2002-2004, 131-142; 2010, 55-70; Тошева 1998-1999: 133-149; Абрамовић 2003; Bogunović 2006; Просен 2006: 167-203; Ignjatović 2007: 179-229; Борић 2008: 179-192; Црвенковић 2011, 99-113.

9] Бабац, Д. М. и др. 2012: 57-119.

10] Архив Југославије, фонд Двор КЈ бр. 74, ф. 545-557.

11] Бабац, Д. М. и др. 2012: 57-119; Архив Југославије, фонд Двор КЈ бр. 74, ф. 372

12] Ивановић 1993.

13] Архив Југославије, фонд Двор КЈ бр. 74, ф. 367.

14] Архив Југославије, фонд Двор КЈ бр. 74, ф. 363.

15] Тошева 1994: 133-149.

16] Петрановић 1988.

17] Кадијевић 2005.

18] Столић 2006: 331-350.

19] J. K. Nelson, R. Zeckhauser 2008.

20] Извештаји С. Смирнова краљу Александру Првом: АJ, фонд Двор Краљевине Југославије бр. 74, ф. 515, 516; Поповић 1930 : $43,48$.

21] Политика, 3. децембар 1929, 2.

22] О животу и раду поменутих аутора в.: Несторовић 1973: 339379; Шкаламера 1983: 109-129; Тошева: 302-307; Кадијевић 1994в: 181-192; 1994a: 243-254; 1997a: 147-149; 1997б: 221255; 1998-1999: 115-132; Миленковић 1997; Просен 2001: 89104; 2006:167-203; Kallestrup 2006: 163-168, 232.

23] Архив Југославије, фонд Двора КЈ бр. 74, ф. 369 в.: Предрачун и планови од 8. марта 1926. године компаније Бачић д. д. (за централно грејање и здравствене уређаје) из Загреба; Досије са плановима техничког бироа Sulcer frères из Букурешта послат Управи двора 15. августа 1930. године.

24] Архив Југославије, фонд Двор КЈ бт. 74, ф. 366-371.

25] Карађорђевић 1990

26] Југовић 1996: 100.

27] Кадијевић 1994а: 243-254; 1998-1999: 115-132.

28] Кадијевић 1997б: 221-255.

29] Кадијевић 2010: 55-70.

30] Ignjatović 2007: 179-229.

31] Исй $о$.

32] Кадијевић 2010: 55-70.

33] Архив Југославије, фонд Двор КЈ бр. 74, Документација ЗЗСКГБ о Дворском комплексу на Дедињу.

34] Архив Југославије, фонд Двор КЈ бр. 74, ф. 368.

35] Документација 33СКГБ о Дворском комплексу на Дедињу.

36] Упоредити са димњацима присутним на грађевинама: Вујовић 1986: $128-144$

37] Архив Југославије, фонд Двор КЈ бр. 74, ф. 372.

38] Бабац, Д. М. и др. 2012: 57-119.

39] Исйо.

40] Архив Југославије, фонд Двор КЈ бр. 74, ф. 368.

41] Кухиња је једина од пропратних грађевина подигнутих у првој фази формирања Дворског комплекса на Дедињу чије фасаде нису обложене каменом оплатом већ су малтерисане: Документација ЗЗСКГБ.

42] Видети: Кадијевић 1998-1999: 115-132; 2010: 179-192. 


\section{МИЛИЦА МАЂАНОВИЋ}

\section{ЛИТЕРАТУРА:}

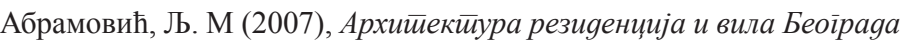
1830-2000, Београд: Карић фондација 2003.

Ackerman, J. S. (1989), The Villa. Form and Ideology of Country Houses, New Jersey: Princeton University Press.

Бабац, Д. М. и др. (2012), Дворски комйлекс на Деgињу, Београд: Завод за уџбенике и наставна средства: 57-119.

Bogunović, S. (2005), Arhitektonska enciklopedija Beograda, t. I, Beograd: Beogradska knjiga.

Борић, Т. (2008), Уметнички опус Ивана Мештровића у дворском комплексу на Дедињу, Наслеђе IX (Београд): 179-192.

Вујовић, Б. (1986), Умейносй обновљене Србије: 1797-1848, Београд: Просвета: 128-144.

Дероко, А. (1964), Фолклорна архиӣекӣура у Јуїославији, књ. II, Београд: Научна књига.

Дероко, А. (1968), Сйара варошка кућа, Београд: Научно дело.

Ивановић, М. В. (1993), Дворови на Деgиюу: 'Срйски Забрағени іраg', Београд: Туристичка штампа.

Ignjatović, A. (2007), Jugoslovenstvo u arhitekturi 1904-1941, Beograd: Građevinska knjiga.

Јовановић, М. (1994), Краљ Алексанgар и руски умейници, у: Руска емиграција у српској култури XX века, том I, ур. Сибиновић М., Београд: Филолошки факултет, Катедра за славистику и Центар за научни рад: 93-97.

Југовић, М. Р. (1996), Инџинири у окружју крушевачком 1834-1924, ПИНУС зайиси 6 (Београд): 100.

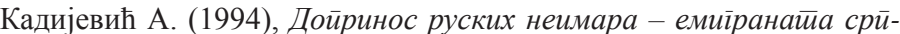

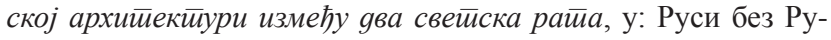
сије. Српски Руси, ур. Бранковић 3., Београд: Дунај: 243-254.

Кадијевић, А. (1994), Николај Пейрович Краснов, у: Руси без Русије. Српски Руси, ур. Бранковић 3., Београд: Дунај: 274-275.

Кадијевић, А. (1994), Прилог проучавању дела архитекте Николе Краснова у Југославији (1922-1937), Саойшйена Р333СК XXVI, Београд: Републички завод за заштиту споменика културе Србије: 181-192.

Кадијевић, А. (1997), Јеgан век йражења нащионалноі сииила у срйској архийекйури (среgина XIX -среgина XX века), Београд: Грађевинска књига: 147-149.

Кадијевић, А. (1997), Рад Николаја Краснова у Министарству грађевина Краљевине СХС/Југославије у Београду од 1922. до 1939. године, Гоgишњак їpaga Беоїраga (у даљем тексту ГГБ) XLIV (Београд): 221-255.

Кадијевић А. (1998-1999), Београдски период рада архитекте Виктора Викторовича Лукомског (1920-1943), ГГБ XLV-XLVI (Београд): 115-132.
Кадијевић А.(2002-2004), Улога руских емиграната у београдској архитектури између два светска рата, ГГБ XLIX-L (Београд): $131-142$.

Кадијевић, А. (2005), Естиейика архииекииууре акаяемизма (XIX-XX век), Београд: Грађевинска књига.

Кадијевић, А. (2010), О архитектури југословенског посланства у Анкари, Наслеђе XI (Београд): 55-70.

Kallestrup, S. (2006), Art and design in Romania 1866-1927, New York: Boulder: 163-168, 232

Карађорђевић, Петар II (1990), Живой јеgног̄ краља : мемоари Петра II Карађорђевића, Београд: Ново дело.

Nelson, J. K, Zeckhauser, R. (2008), The Patron's Payoff, Conspicious Commissions in Italian Renaissance Art, New Jerssey: Princeton University press.

Несторовић, Б. (1973), Постакадемизам у архитектури Београда (1919-1941), ГГБ ХХ (Београд): 339-379.

Петрановић, Б. (1988), Исйорија Јуіославије : Краљевина Југославија, књ. I, Београд: Нолит.

Поповић, П. Ј. (1930), Краљ Алексанgар Први, љубииель архииек-

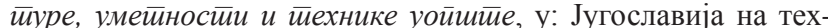
ничком пољу 1919-1929, Београд: Удружење југословенских инжењера и архитеката: 43, 48.

Просен, М. (2001), Прилог познавању београдског опуса Григорија И. Самојлова, Наслеђе III (Београд): 89-104.

Просен, М.(2006), Градитељски опус архитекте Александра Ђорђевића (1890-1952), Наслеђе VII (Београд): 167-203.

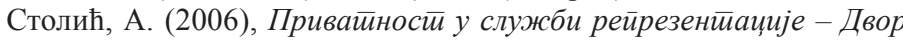
йослеgюих Обреновића, у: пр. А. Столић и Н. Макуљевић, Приватни живот код Срба у деветнаестом веку : Од краја XVIII века до почетка Првог светског рата, Београд: Clio: 331-350.

Тошева, С. (1994), Кайийална дела руских архийекайа у Беоїраяу, y: Руска емиграција у српској култури XX века, том I, ур. Сибиновић М., Београд: Дунај: 302-307.

Тошева, С. (1998-1999), Конкурс за Бели двор на Дедињу, ГГБ XLV-XLVI (Београд): 133-149.

Трпковић, Б. (1985), Стари двор на Дедињу, Свеске иситоричара умейностии XVI (Београд): 100-105.

Црвенковић, Б. (2011), Бахчисарајска фонтана у Краљевском двору на Дедињу, Архив XII, бр. 1-2 (Београд): 99-113.

Шкаламера, Ж. (1983), Архитекта Никола Краснов (Москва, 1864 Београд, 1939), Свеске ДИУС XIV (Београд): 109-129. 


\title{
АРХИТЕКТУРА ПРАТЕЋИХ ГРАЪЕВИНА ДВОРСКОГ КОМПЛЕКСА
}

\author{
Summary: MILICA MADJANOVIĆ
}

\section{THE ARCHITECTURE OF THE ANCILLARY BUILDINGS OF THE ROYAL COMPLEX IN DEDINJE}

The decision of King Alexander I Karadjordjević to have a new royal family residence built in a secluded location, away from urban commotion, and then to enlarge the complex with a residence for the princes, had to be materialized in the form of a prestigious edifice of a layered communicational character for the designing, construction and furnishing of which were hired prominent architects, engineers, artists and workshops such as the architects Nikolaj Krasnov, Živojin Nikolić, Viktor Lukomski, Aleksandar Djordjević, Grigorije Samojlov, the engineer Sergej Smirnov, and the Viennese workshop of Bernhard Ludwig.

Sited on a remarkably suitable location such as the highest of Dedinje hillocks, the royal residence complex was architecturally shaped in two phases which saw the construction of the dominant central palace and a number of ancillary buildings. The interior decoration and furnishing of the residence was not completed until 1934, but the first phase of shaping the complex, centred on the Royal Palace designed as a carefully composed semiotic communicational system, can be followed from 1924 to 1929. In the second phase, from 1934 to 1937, which resulted in the creation of a coherent well-rounded whole, the complex received the White Palace. In contrast to the initial design conceived to match the forms of the Royal Palace, it echoed English Palladian architecture, exhibiting elegant outlines that make it one of the most important works of the mature phase of Serbian academism.

The spaciousness of palace grounds, isolated from the dense urban fabric of the capital city, made it possible to relieve the Royal Palace, the central building of the first phase, of the mechanisms of the household's day-to-day life by placing them in purpose-built ancillary structures: the reception, household, kitchens and palace guard buildings. Inspired by the belief that the ancillary buildings with their appealing façades, composed under the influence of the Royal Palace, and their carefully designed layouts, signed by the architect Živojin Nikolić, a still insufficiently illuminated figure, would have attracted greater attention from the professional community had they not been overshadowed by the imposing presence of the Royal and White Palaces, this paper offers an architectural analysis as a first step towards a more comprehensive approach to these structures.

\section{ILLUSTRATIONS}

Fig. 1 Straw House, front façade (CHPIB Documentation, V-2389/8)

Fig. 2 Palace Gendarmerie building, rear façade (CHPIB Documentation, V-2406/15)

Fig. 3 Palace Guard building (CHPIB Documentation, V-2406/17)

Fig. 4 Household building, general view (CHPIB Documentation, V-2406/27)

Fig. 5 Palace Kitchens, front façade (CHPIB Documentation, V-2406/10) 